\title{
Effects of mating on oviposition, and possibility of parthenogenesis of three domestic cockroach species, the American cockroach, Periplaneta americana; the Smoky brown cockroach, Periplaneta fuliginosa; and the German cockroach, Blattella germanica
}

\author{
Xingfu XIaN \\ BSI Institute of Biological Science, Azusawa 2-17-7, Itabashi-ku, Tokyo, 174-0051 Japan
}

(Received: 16 July 1997; Accepted: 11 October 1997)

\begin{abstract}
Key words: cockroach, adult lifespan, oviposition, ootheca, parthenogenesis, sexual reproduction
\end{abstract}

\begin{abstract}
Three domestic cockroach species, the American cockroach, Periplaneta americana; the Smoky brown cockroach, Periplaneta fuliginosa; and the German cockroach, Blattella germanica were used in this experiment to determine the effect of mating on oviposition and possibility of parthenogenesis. In comparison with mated females, unmated females of $P$. americana and $P$. fuliginosa had a longer adult lifespan, but produced obviously fewer oothecae, including many malformed oothecae. The malformed ootheca rate was higher than $60 \%$. However, unmated females of $B$. germanica were similar to mated females in adult lifespan and the oviposition cycle, and all the oothecae produced by unmated females were normally formed. Parthenogenesis was found in $P$. americana and $P$. fuliginosa. The hatchability of oothecae produced by unmated females, which the malformed oothecae were not counted, was $18.7 \%$ in $P$. americana, and $16.7 \%$ in $P$. fuliginosa. All the parthenogenetic progeny were females. Parthenogenesis was not found in $B$. germanica, oothecae deposited by unmated females were desiccated and fell off before new oothecae were produced.
\end{abstract}

\section{INTRODUCTION}

Cockroaches are common and persistent pests in commercial, domestic and institutional premises. They are known to carry a variety of bacteria and other pathogenic organisms (Roth and Willis, 1957), and immunological studies also suggests that they may give rise to serious allergic reactions, including asthma, in a substantial proportion of the allergen-sensitive population (Berton and Brown, 1964, 1972; Kawakami et al., 1982; Berns, 1987; Chapman, 1993). Although $P$. americana, $P$. fuliginos $a$ and $B$. germanica are among the pests in homes and stores in Japan, their physiological and ecological characteris- tics have not been well investigated, especially on the aspect of reproduction.

Reproduction is a vital factor in the biology of an insect species, and cockroaches illustrate this principle perfectly. Cockroaches become troublesome pests to human life because they have a strong vitality and high reproductive ability to expand their sphere of influence. Hence, the reproduction of cockroaches is a subject of more than academic interest. Parthenogenesis, a special reproductive system, is widely found in insects. Many insect species, such as aphids and weevils, can make use of parthenogenesis to rapidly increase their population when the environment is advantageous to propagate. Some parasitic bee and fly species also use 
parthenogenesis to leave progeny in a temporary absence of males to copulate for sexual reproduction. On the other hand, the banded psocid, Liposcelis bostrichophilus $\mathrm{B}$, has to use parthenogenesis to leave progeny because all the insects are female.

However, parthenogenesis of cockroaches has seldom been mentioned. Blattella orientalis (Short and Edward, 1991), Pycnoscelus surinamensis (Matthey, 1948), Supella supellectitium (Roth and Willis, 1954) and $P$. americana (Griffiths and Tauber, 1942) have reported on this subject. In Japan, there have been no data available regarding parthenogenesis of cockroaches.

The objectives of this experiment were to study the reproduction of three domestic cockroach species, $P$. americana, $P$. fuliginosa and $B$. germanica, especially in oviposition and parthenogenesis.

\section{Materials and Methods}

Specimens of $P$. americana, $P$. fuliginosa and $B$. germanica were used in the present study. They had been hatched in the laboratory from eggs taken from stock cultures on a diet of rolled feed for mouse propagation (Oriental Yeast Industry Co.). Water was supplied at all times. In June, the final instar female nymphs of the cockroaches were selected from culture tanks and removed to new culture tanks. When the females newly emerged to adult, they were immediately removed to $15 \times 12 \times 11$ $\mathrm{cm}$ plastic culture cases, separated into a sexual reproduction group and a parthenogenesis group. The adult females of $P$. americana and $P$. fuliginos $a$ were individually placed in culture cases. Each group consisted of 10 cases ( 10 females). Five adult females of $B$. germanica were transferred together into one culture case, and each group consisted of 6 cases ( 30 females). In the sexual reproduction group, females were kept with males from the time of emergence until death. When the males died, they were replaced with other males from the culture tanks. In the parthenogenesis group, unmated females were kept without males during the adult life time.

All insects were kept in an incubator where the temperature was maintained at $30^{\circ} \mathrm{C}$ and the humidity was uncontrolled throughout the experiment. Food, water and harbourage were supplied at all times. Newly-produced oothecae of $P$. americana and $P$. fuliginosa were transferred from the culture cases into glass specimen tubes and incubated at $30^{\circ} \mathrm{C}$. When nymphs hatched from oothecae, they were transferred to larger plastic tanks $(65 \times 45$ $\times 45 \mathrm{~cm}$ ) and maintained at $30^{\circ} \mathrm{C}$ with food, water and harbourage until adult. Oothecae that did not hatch after a period of 6 weeks were retained for more 3 weeks before being discarded. All the nymphs hatched from the parthenogenesis group were cultured. In the sexual reproduction group, 121 and 118 nymphs of $P$. america$n a$ and $P$. fuliginosa were reared and the others were discarded. In $B$. germanica, when oothecae fell off from females, they were collected and searched for hatching. All the hatched nymphs were discarded.

\section{RESUlts}

\section{Adult longevity and oviposition of female cockroaches}

In $P$. americana, the lifespan of adult females which mated with males was approximately 6 months (187 \pm 14 days, range 145-227 days). Unmated females lived for 212 \pm 19 days (range 169-274 days), which were longer than that of the mated females (Table 1). Newly emerged females produced the first ootheca after an emergence time of $10.2 \pm 0.8$ days when mated and slightly later (12.4 \pm 2.1 days) when unmated. Mated females produced an average of $34.1 \pm 3.5$ oothecae (range 22-43) per female during their life. In mated females, the oviposition cycle was approximately 4 days $(4.2 \pm 0.7$ days, range $3-6$ days) in the first 2 months and 6 days (6.3 \pm 1.3 days, range $4-10$ days) in 
Table 1. Adult longevity and oviposition of female cockroaches.

\begin{tabular}{clcccc}
\hline \hline Species & No. of & $\begin{array}{c}\text { Mean } \\
\text { insects }\end{array}$ & $\begin{array}{c}\text { Mean preovi- } \\
\text { (days) }\end{array}$ & $\begin{array}{c}\text { Mean no. } \\
\text { position period } \\
\text { (days) }\end{array}$ & $\begin{array}{c}\text { oothecae } \\
\text { per female }\end{array}$ \\
\hline \multirow{2}{*}{ P. americana } & Mated & 10 & $187 \pm 14$ & $10.2 \pm 0.8$ & $34.1 \pm 3.5$ \\
& Unmated & 10 & $212 \pm 19$ & $12.4 \pm 2.1$ & $8.9 \pm 4.2$ \\
\hline \multirow{2}{*}{ P. fuliginosa } & Mated & 10 & $149 \pm 12$ & $9.8 \pm 1.1$ & $24.5 \pm 2.7$ \\
& Unmated & 10 & $181 \pm 17$ & $14.1 \pm 2.7$ & $6.2 \pm 3.1$ \\
\hline \multirow{2}{*}{ B. germanica } & Mated & 30 & $98 \pm 7$ & $7.1 \pm 1.1$ & $3.8 \pm 0.8$ \\
& Unmated & 30 & $101 \pm 7$ & $7.3 \pm 1.0$ & $3.9 \pm 1.1$ \\
\hline
\end{tabular}

Table 2. Viability of oothecae of cockroaches.

\begin{tabular}{clcccrcc}
\hline \hline Species & & $\begin{array}{c}\text { Total } \\
\text { oothecae }\end{array}$ & $\begin{array}{c}\text { No. of } \\
\text { malformed } \\
\text { oothecae }\end{array}$ & $\begin{array}{c}\text { Malformed } \\
\text { ootheca } \\
\text { rate }(\%)\end{array}$ & $\begin{array}{c}\text { Hatched } \\
\text { oothecae }\end{array}$ & $\begin{array}{c}\text { Hatch- } \\
\text { ability } \\
(\%)^{*}\end{array}$ & $\begin{array}{c}\text { Mean no. } \\
\text { of nymphs } \\
\text { per ootheca }\end{array}$ \\
\hline \multirow{2}{*}{ P. americana } & Mated & 341 & 12 & 3.5 & 314 & 95.4 & $12.0 \pm 0.3$ \\
& Unmated & 89 & 57 & 64.0 & 6 & 18.7 & $11.0 \pm 1.8$ \\
\hline \multirow{2}{*}{ f. fuliginosa } & Mated & 245 & 3 & 1.2 & 230 & 95.0 & $11.8 \pm 0.2$ \\
& Unmated & 62 & 38 & 61.3 & 4 & 16.7 & $10.0 \pm 1.0$ \\
\hline \multirow{2}{*}{ B. germanica } & Mated & 114 & 0 & 0 & 114 & 100 & $* *$ \\
& Unmated & 117 & 0 & 0 & 0 & 0 & 0 \\
\hline
\end{tabular}

*. The malformed oothecae were not counted in.

**, Not counted.

the later months, and their oviposition was stopped at the last $16 \pm 4$ days before they died. The oviposition cycle of unmated females was an average of $8.9 \pm 2.1$ days (range $5-15$ days) in the first term and $17.0 \pm 5.2$ days (range 6-30 days) in the last term, which were significantly longer than that of mated females, an average of $8.9 \pm 3.2$ oothecae was produced per female. As compared with the mated females, unmated females also were early to stop oviposition, the last ootheca was produced at $25 \pm 11$ days before death. Two unmated females completely ceased to produce ootheca after emergence time of 40-50 days. Many malformed oothecae which had no eggs in the ootheca case were obtained from the parthenogenesis group, the rate of malformed oothecae was about $64 \%$ (Table 2). But the oothecae produced by mated females were almost normally formed, and the malformed oothecae only $3.5 \%$.
In $P$. fuliginosa, the lifespan of adult females which mated with males was 149 \pm 12 days (range 117-174 days), but unmated females lived longer ( $181 \pm 17$ days, range 131-236 days) than mated females. Mated females produced the first ootheca $9.8 \pm 1.1$ days after emergence. They produced an average of $24.5 \pm 2.7$ oothecae (range 17-35) per female during their life time. On the other hand, unmated females produced the first ootheca $14.1 \pm 2.7$ days after emergence, which was longer than that of the mated females. Each unmated female produced approximately 6 oothecae $(6.2 \pm 3.1$, range $3-14)$, which was only $25 \%$ of that produced by mated females. The unmated females also were early to stop oviposition in comparison with the mated females. The rate of malformed oothecae without eggs was about $60 \%$ in the parthenogenesis group, while it was only $1.2 \%$ in the sexual reproduction group. 
Table 3. The sex ratio in progeny.

\begin{tabular}{|c|c|c|c|c|c|}
\hline \multirow{2}{*}{ Species } & \multirow{2}{*}{ Reproductive type } & \multirow{2}{*}{ No. of insects } & \multicolumn{2}{|c|}{ No. of progeny } & \multirow{2}{*}{$\begin{array}{c}\text { Sex ratio } \\
\text { オ: 우 }\end{array}$} \\
\hline & & & $\pi$ & 우 & \\
\hline \multirow{2}{*}{ P. americana } & Sexuality & 121 & 64 & 57 & $1.12: 1$ \\
\hline & Parthenogenesis & 66 & 0 & 66 & - \\
\hline \multirow{2}{*}{ P. fuliginosa } & Sexuality & 118 & 56 & 62 & $0.90: 1$ \\
\hline & Parthenogenesis & 40 & 0 & 40 & - \\
\hline
\end{tabular}

The lifespan of adult females of $B$. germanica was notably shorter than that of $P$. americana and $P$. fuliginosa. The mated females lived about 98 days and the unmated females about 101 days. In contrast to $P$. americana and $P$. fuliginosa, mating was not recognized to influence the adult lifespan of females. Mated females produced the first ootheca $7.1 \pm 1.4$ days after emergence, and an average of 3.8 oothecae per female was produced during their life time. The oviposition cycle of unmated females was very like that of the mated females, the first oothecae were produced $7.3 \pm 1.0$ days after emergence, and $3.9 \pm$ 1.1 oothecae were produced during their life time. All the oothecae were normally formed and they were carried at the tail of females for about 20 days before a new ootheca was deposited in the parthenogenesis group, similarly in the sexual group.

\section{Parthenogenesis}

In the present study, a total of 32 normally formed oothecae was produced by 10 unmated females of $P$. americana, and about 66 nymphs hatched from 6 of their unfertilized oothecae. The hatchability was $18.7 \%$. On the other hand, the hatchability of oothecae produced by mated females was about 95\%, and an average of 12 nymphs hatched per ootheca.

Twenty-four normally formed oothecae were produced by unmated females of $P$. fuliginosa, but only 4 oothecae hatched. The hatchability was $16.7 \%$ similar to $P$. americana. An average of 10 nymphs hatched per ootheca. On the other hand, hatchability of oothecae produced by mated females was 95\%, greatly higher than the parthenogenesis group. An average of 11.8 nymphs hatched per ootheca.

All the nymphs hatched from the oothecae produced by unmated females of $P$. americana and $P$. fuliginosa were females. The male progeny have not been found in the parthenogenesis group. However, the sex ratio of male to female in the progeny from the sexual reproduction group was about $1.1: 1$ in $P$. americana and $0.9: 1$ in $P$. fuliginosa, respectively (Table 3 ).

On the other hand, parthenogenesis did not operate in $B$. germanica, none of the unfertilized eggs hatched. Oothecae deposited by unmated females were desiccated and fell off before a new ootheca was produced. All the oothecae produced by mated females were hatched.

\section{Discussion}

In the present study, the adult lifespan of unmated females of $P$. americana and $P$. fuliginosa was significantly longer than that of mated females. This observation agrees with that of Griffiths and Tauber (1942). Short and Edwords (1991) also observed the similar results in $B$. orientalis. The difference in adult lifespan between mated and unmated females suggests that the oviposition frequency may be an important factor on the adult longevity of females. It is conjectured that oogenesis consumes great amounts of nutrition and energy so that the lifespan of adult females is shortened along with the increase of oviposition frequency. The unmated females had a longer lifespan than the mated females because their ovi- 
position cycle was longer and produced fewer eggs.

On the other hand, the adult lifespan of mated and unmated females of $B$. germanica was quite similar. That also can be attributed to the reproduction because the oviposition cycle was similar between the two groups. Ogata (1976) reported that the adult lifespan of $B$. germanica was about $5-8$ months at $25^{\circ} \mathrm{C}$ which differs from this experiment. It is probable that the differences in culture conditions, such as temperature and food, and regional lineage, influence the adult longevity of the cockroach.

The preoviposition period that an interval from emergence to producing the first ootheca was seen in difference between mated and unmated females. Unmated females of $P$. americana and $P$. fuliginosa had a slightly longer period than that of mated females. Mating may be to stimulate females to produce the first ootheca.

The effect of mating on reproduction was demonstrated in the oviposition cycle of $P$. americana and $P$. fuliginosa. For example, mated females of $P$. americana produced an average of 34 oothecae during their lifespan, but the unmated females isolated from males only produced 9 oothecae including many malformation during their lifespan. Same phenomenon was also reported by Griffiths and Tauber (1942) and Roth and Willis (1954). The results suggest that action of copulation or reception of spermatophore is an important factor to stimulate the development of oocytes in the ovary and accelerate ovulation. But in B. germanica, the oviposition cycle is controlled by hormone feedback, so that the effect of mating is difficult to expression. When ootheca is carried in the tail of the female, the secretion of gonadotrophic hormone is restrained, so the development of the next oocytes which is stimulated by the gonadotrophic hormone is inhibited and the ovulation is suspended until the ootheca fell off from the female (Bell, 1981).

Parthenogenesis is considered to be a possible occurrence among the wild cockroaches. In a temporary absence of males which often occurs in tropical forests, an unmated female has to leave its progeny by parthenogenesis. The best-known example of this type of reproduction in cockroaches is $P$. surinamensis which in the Indo-Malaysia area occurs sexually, but in North America and Europe, where the cockroach has been introduced, they are parthenogenetic, producing only females (Matthey 1948). Gould and Deay (1938) stated that it is generally believed that parthenogenesis does not occur in domestic cockroach species or at most is a rare occurrence in $P$. americana. However, Griffiths and Tauber (1942) reported that some unfertilized eggs of $P$. americana and $P$. fuliginosa could complete their embryogenesis to hatch which agrees with the results of the present study.

In agreement with the results of Short and Edwords (1991), nymphs from oothecae produced by parthenogenesis were exclusively females in the present study. This may mean that in the unfertilized egg, the first maturation division, i.e., reducing division, is suppressed and only the equational division occurs in cleavage nucleus to form a diploid set chromosomes. Another possibility is that the maturation divisions occur normally in the eggnucleus and polar bodies, which have a haploid set of chromosomes, and the eggnucleus and one of the polar bodies fuse again to form a nucleus having a diploid set of chromosomes in the unfertilized eggs. Thus, the parthenogenetic nymphs as a rule possess a diploid set of chromosomes and the genotype exactly like their mothers.

The nominal hatchability of parthenogenetic oothecae, which the malformed oothecae were not counted, was about 16$19 \%$ in $P$. americana and $P$. fuliginosa, but the oothecae produced by parthenogenesis were few and many of them were malformed, so that the real reproducibility should be lower than $2 \%$ as compared with the sexual reproduction in the pre- 
sent study. It seems that parthenogenesis is a possible but infrequent phenomenon for the reproduction in $P$. americana and $P$. fuliginosa. It is also suggested that parthenogenesis is not important in reproduction of the three species in nature.

\section{REFERENCES}

Bell, W. J. (1981) The Laboratory Cockroach. 161 pp., Chapman and Hall, London.

Berns, B. (1987) The invisible enemy: cockroach allergies. Pest Control Technol., 65: 55-57.

Berton, H. S. and H. Brown (1964) Insect allergy preliminary studies of the cockroach. J. Allergy, 35: 506-513.

Berton, H. S. and H. Brown (1972) Cockroach asthma. Br. J. Dis. Chest, 66: 61-66.

Chapman, M. D. (1993) Dissecting cockroach allergens. Clin. Exp. Allergy, 23: 459-461.

Gould, G. E. and H. O. Deay (1938) Biology of the American cockroach. Ann. Entomol. Soc. Am., 31: 489-498.

Griffiths, J. T. and O. E. Tauber (1942) Fecundity, longevity, and parthenogenesis of the American cockroach, Periplaneta americana L. Physiol. Zool., 14: 196-209.

Kawakami, T., C. Suto, T. Yagura and N. Kumada (1982) Studies on cockroach allergy, I. Allergenicity of common domestic cockroach of Japan. Jpn. J. Sanit. Zool., 33: 233-238 (in Japanese with English summary).

Matthey, R. (1948) La formulae chromosomal de Pycnoscelis surinamensis L. Race bisexual et race parthenogenetique. Arch. Julius Klaus-Stift, 23: 517520.

Ogata, K. (1976) Studies on establishing factors of domeciliary cockroaches, 2. Experimental observations of development of German cockroaches in various environments. Jpn. J. Sanit. Zool., 27: 411421 (in Japanese with English summary).

Roth, L. M. and E. R. Willis (1954) The reproduction of cockroaches. Smithson. Misc. Collect., 122: 1-49.

Roth, L. M. and E. R. Willis (1957) The medical and veterinary importance of cockroaches. Smithson. Misc. Collect., 134: 1-147.

Short, J.E. and J.P. Edwords (1991) Reproductive and developmental biology of the Oriental cockroach Blatta orientalis (Dictyoptera). Med. Vet. Entomol., 5: 385-394.

\section{摘 要}

配偶がワモンゴキブリ，クロゴキブリ及び チャバネゴキブリの産卵に及ぼす影響と 単為生殖の可能性

洗幸夫

BSI 生物科学研究所

（干174-0051 東京都板橋区小豆沢 2-17-7）

配偶の有無が 3 種家屋住居性ゴキブリの産卵に及ぼ す影響及び単為生殖の可能性について調べた。ワモンゴ キブリとクロゴキブリでは処女雌は配偶している䊒より 成虫の生存期間が長かったが，チャバネゴキブリでは雌 成虫の生存期間には配偶の影響がみられなかった。ワモ ンゴキブリでは配偶している雌は平均で 34 卵鞘を産下 したが，処女雌は 8.9 卵䩗しか産下しなかった。 クロゴ キブリ6同様で，処女雌の産下した卵鞘数は 6.2 で，配 偶している雌の $24.5 \%$ であった。 また, 処女踓の産下し た卵鞘には卵の入っていない奇形卵鞘が多数含まれ，そ の比率はワモンゴキブリでは $64 \%$ ，クロゴキブリは 61\%であった.これに対して，チャバネゴキブリでは処 女雌の産卵数は配偶している雌とほぼ同数で, 奇形卵鞘 あみられなかった，単為生殖はワモンゴキブリとクロゴ キブリに観察された。 ワモンゴキブリでは未受精卵鞘の 躬化率は $18.7 \%$ で，クロゴキブリでは $16.7 \%$ グあった. 単為生殖で得られた子孫はすべて雌であった。 チャバネ ゴキブリでは単為生殖が認められなかった。 